Religious Educator: Perspectives on the Restored Gospel

4-1-2011

\title{
The Sermon on the Mount in the Light of the Temple
}

Alan Taylor Farnes

John W. Welch

Follow this and additional works at: https://scholarsarchive.byu.edu/re

\section{BYU ScholarsArchive Citation}

Farnes, Alan T. and Welch, John W. "The Sermon on the Mount in the Light of the Temple." Religious Educator: Perspectives on the Restored Gospel 12, no. 1 (2011). https://scholarsarchive.byu.edu/re/ vol12/iss $1 / 5$

This Article is brought to you for free and open access by the Journals at BYU ScholarsArchive. It has been accepted for inclusion in Religious Educator: Perspectives on the Restored Gospel by an authorized editor of BYU ScholarsArchive. For more information, please contact scholarsarchive@byu.edu, ellen_amatangelo@byu.edu. 


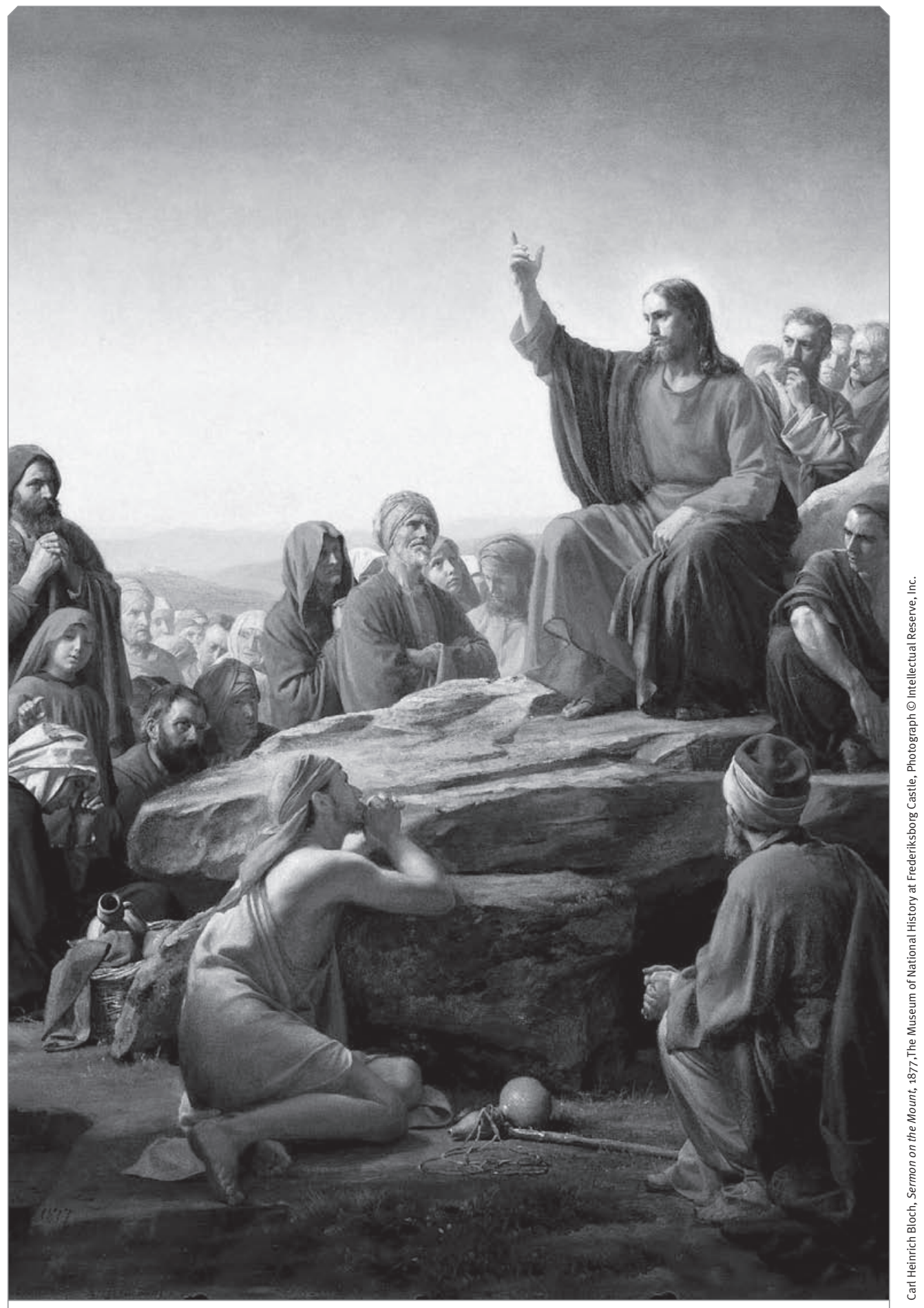

The Sermon on the Mount orients us and redirects our attention. 


\section{The Sermon on the Mount in the Light of the Temple}

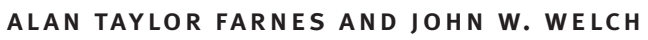

Alan Taylor Farnes (alan.taylor.farnes@byu.edu) is a senior in Ancient Near Eastern Studies at BYU.

John W. Welch (welchj@byu.edu) is Robert K. Thomas University Professor of Law at BYU and author of The Sermon on the Mount in Light of the Temple (London: Ashgate, 2009).

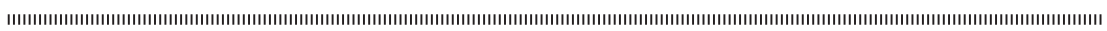

Farnes: In Iggo you wrote a book called The Sermon at the Temple and the Sermon on the Mount. Tell me about the relationship between that book and your new book published in London by Ashgate.

Welch: Well, it is an interesting story how these two books are related. My first book about the Sermon at the Temple was published by Deseret Book and FARMS. Then in I999, a paperback edition was published. I took the opportunity at that time to add enough new material, including a whole new chapter on ritual applications and study, that the book was given the expanded title of Illuminating the Sermon at the Temple and Sermon on the Mount. LDS interests in 3 Nephi are the dominant focus of those books. Out of them has grown the 2009 book, aimed mainly at scholars with more particular biblical interests and also at a wider, nondenominational readership. These have been steps in a long process of trying to get my hands around these wonderful scriptural texts.

Farnes: How long have you been working on the Sermon on the Mount?

Welch: The Sermon on the Mount has been one of my favorite texts for forty-five years. In 1966, when I was a young missionary in the LTM 
(Language Training Mission, predecessor of the Missionary Training Center), I had an inspiring zone leader who challenged us and kept us as busy as possible. One day he walked up to me and said, in German, "On Thursday I would like you to memorize and pass off for me the entire Sermon on the Mount." I did so, and thus began a lifelong interest for me in the Sermon on the Mount in Matthew chapters 5-7. Unfortunately, not everyone these days knows what the Sermon on the Mount is.

Farnes: What do most people think the sermon is?

Welch: Many people think of it as just the Beatitudes. Lots of people, of course, know the Lord's Prayer, but many do not associate it in their minds with the Sermon on the Mount, even though it is embedded right in the middle of that text. Learning at a young age to appreciate the whole of the Sermon on the Mount was one of the best things I have ever done in my life. Having memorized this text, I used passages from it in Germany virtually every day of my mission.

Farnes: Could you give us a verse in German that you remember?

Welch: Sure. Selig sind die barmherzigen; denn sie werden Barmherzigkeit erlangen (Blessed are the merciful, for they shall gain mercy). That's is the Luther translation of the fifth Beatitude. Memorizing this text made me really internalize its messages, knowing them not just mentally, but literally by heart.

Farnes: That must have influenced you every time you have read it since.

Welch: Yes, whenever I run across an echo or some kind of parallel in the scriptures or elsewhere, it jumps out at me, which has made research and discovery a lot more exciting and possible. Otherwise I might read over things and miss their connections with the Sermon on the Mount.

Farnes: What were some of the things you learned about the Sermon on the Mount right after your mission?

Welch: After I graduated from BYU in I 970, I studied at Oxford, where I focused on Greek philosophy but also took a number of courses and seminars on the New Testament, one in particular on the Greek manuscripts of the New Testament. And there, I learned a lot about the manuscript traditions of the Sermon on the Mount, partly again because I was already especially interested in that text. For example, I learned about the Greek texts of Matthew $5: 22$, about being angry with your brother "without a cause." But the phrase translated as "without a cause" is just one word in the Greek, and that word is not present in some of the earliest manuscripts. Interestingly it's not present in 3 Nephi 12 either. And I thought that was more than coincidence. I also 
continued working on my chiasmus projects, and when I edited and published the book Chiasmus in Antiquity, one of the chapters was on chiasmus in the New Testament. I mention there the efforts by some people who have tried with varying degrees of success to argue that the Sermon on the Mount is chiastically structured. I do not think the idea works very well in that case, but this was another Sermon on the Mount issue that I worked on early in my academic pursuits. So I have been working on this text in various ways for quite a while.

Farnes: You coined the term "Sermon at the Temple," which has been adopted by the Latter-day Saint community. What is it like to coin a term like that?

Welch: As Shakespeare asks, "What is in a name?" But actually the answer is, a lot. Labels are important. If we call something by the wrong name, it can convey a lot of the erroneous impressions. It has been very gratifying to me that this name has stuck, that it has been serviceable to people. Of course, neither the term "Sermon on the Mount" nor "Sermon at the Temple" is found in the text of Matthew or 3 Nephi, but it is now clear from 3 Nephi I I: I that this material was delivered by Jesus at the temple, and that would seem to be an important fact. Thus, the name "Sermon at the Temple" encapsulates much of what this text is all about, and so it orients people and redirects their attention. It's a little thing, but it's a good thing that can help people see things they might otherwise not have noticed.

Farnes: When did you come up with the term?

Welch: The phrase "Sermon at the Temple" was first published in a FARMS update in March 1988 , but the idea came when was when I was trying, a few weeks earlier, to solve some problems regarding the Sermon on the Mount. At that time I was director of Special Projects at the BYU Religious Studies Center, and I had an office in the basement of the old Joseph Smith Building. I loved that office: It had no telephone, so it was a good place to work without interruption. I began by slowly rereading 3 Nephi I I - I 4 in an effort to respond in a systematic, comprehensive way to some criticisms that people had raised against the Book of Mormon, because the Sermon on the Mount is so closely replicated there in 3 Nephi. Its appearance there could be a problem for Book of Mormon readers if the Sermon on the Mount was not written until long after the death of Jesus, as some have argued.

Farnes: How do people view the authorship of the Sermon on the Mount today? 
Welch: Indeed, many New Testament scholars have thought that the material in Matthew 5 -7 was compiled by Matthew as a collection of miscellaneous things that Jesus said on various occasions. Fortunately, several non-LDS scholars today are at least seeing it as a pre-Matthean text.

Farnes: Back to your reading of 3 Nephi II-I4. What was different that day in I988?

Welch: The first thing I wanted to find was a way to approach this text. As I stepped back from the text, I asked myself the basic question, "How does one read this text?" And it was clear that one cannot answer this question until one knows what kind of a text it is. If it is a general conference talk, you read it one way. If it is a speech to the PTA, you read it another way. Rhetorically, the audience and the setting of any speech make a difference. What kind of a text is this so-called sermon? Is it a random collection of sayings that have been pulled together in some loose order? Or is there something stronger that holds it together? That day in the basement of the JSB was a rare day for me-it was a session of concentrated effort that went for about seven hours, from 9:00 in the morning until about 4:00 in the afternoon, with no interruptions and, actually, little consciousness of time. I wrestled with the Sermon on the Mount. When I finally heard a bell ring at four o'clock, I thought it was lunchtime, because I had been so absorbed in this text, outlining its details on my green-screened computer. (Believe it or not, we did have computers at that time.)

\section{Farnes: What did you find as you outlined?}

Welch: Well, the more I outlined, the more I saw temple themes and temple phraseology and patterns that we find in other temple texts and experiences. And then, like a bolt out of the blue, it dawned on me that this is a text that is given by Jesus at the temple. And that has made all of the difference. I decided right then no longer to call the sermon in the Book of Mormon the Sermon on the Mount but rather the Sermon at the Temple, because it was given there in a different setting to a different audience and involving other differences. I began looking at those differences in the light of a temple context, and in very subtle ways, everything worked out to see it in that context. That, in and of itself, was very exciting. At about 4:30 p.m., when I stumbled up the stairs to walk back over to my office at the Law School, a friend of mine, Professor Stephen Robinson, happened to walk out of the Joseph Smith Building with me. We started some casual conversation like "What have you been doing today?" So I told him the main ideas, and he was the 
first to hear about this as we walked across campus. I think we both sensed the potential for the idea, but wondered if the idea could be sustained, supported, and substantiated. It was just the beginning of a lot of research, and that is what the last twenty-plus years have been about.

Farnes: So the groundbreaking part of the idea was the context.

Welch: That's right. The people had gathered at the temple in Bountiful, and so I started wondering, "Why? Why were they there at the temple?" Men, women, and children. We aren't told the answer to this question. Maybe the Book of Mormon gives us more credit than we deserve, assuming that we can figure this out without having to be told everything. But to me, it seems pretty obvious that all those faithful people had recently heard the words from the darkness during the three days of destruction and mists of blackness, when Jesus said: "Ye shall offer up unto me no more the shedding of blood" (3 Nephi 9: 19). The old things had been done away, and the people had been told to offer only "a broken heart and a contrite spirit," using a phrase from the Psalms that may have been familiar to them, which now superseded or transcended all the other parts of their former temple practice. But now the people must have been asking themselves, "How does this new law work? What are we to do in our temple now?" I even wonder if the high priest Nephi (who was the great-great-grandson of Alma the Younger, the first chief judge and also a high priest among the Nephites) had a sense that there would be new revelations given to him and his people, and so he had convened a solemn assembly with his people, and they faithfully came. Not all of them came, but a lot of them came. They were gathered, it would seem, hoping and maybe fasting for guidance. They must have been there early in the morning, because so much happened that day. With that background, it is clear that the temple is not a casual part of the narrative in 3 Nephi.

Farnes: What was it that motivated you in publishingyour first book on the Sermon on the Mount?

Welch: A lot of the motivation and assurance came by the bright sparkles in people's eyes, the "ah-ha" moment, when they first heard, even in a very brief explanation, why I was calling it the Sermon at the Temple. At that point in those early months and years, nothing had been published on it, and so it was something that I would bring up in a BYU class or in a Sunday School context or with my student ward where I was serving as bishop. To then watch people come up with their own development of that idea was very reassuring to me. If you go out drilling for oil, and you drill and do not strike oil, you go 
and drill somewhere else. But if you keep striking oil every time you drill, you keep putting down another well, knowing there's a lot of oil down there. And it was that kind of success and excitement that motivated me to keep working on this approach.

\section{Farnes: How have people accepted it?}

Welch: I have many people over the years tell me that this idea is one of the most impressive things they have learned about in a long time, because it changes the whole way they read this important text. Other people tell me that they now understand the temple better because they understand the Sermon on the Mount, and that they understand the Sermon on the Mount better because of the temple. All people can benefit a great deal from this perspective, and general audiences light up when they hear it explained. Shortly after I had begun putting this all together, Hugh Nibley had to take a trip and was going to miss five of his Book of Mormon classes; he asked me if I would substitute for him while he was gone. I said, "Where in the text will the class be when you are gone?" He said, "Right about 3 Nephi chapter Io." I saw this as more than fortuitous. But that opportunity was also a real trial by fire because it was a large class and people expected a Nibley-kind of finished quality. It took those five full classes just to get through the basics of what would become the main chapter in the 1990 book, which goes through what I had identified as the forty-eight stages in the Sermon at the Temple in 3 Nephi I I- I 8. As we went through those steps, one at a time, it was evident from the reactions of the students that the coherence of the idea was really holding together.

Farnes: When did you first present this to academia?

Welch: The 1990 book was published locally by FARMS and Deseret Book. Soon I began wondering how I might possibly present the idea in a way that New Testament scholars would not ignore it or reject it out of hand. As I attended the annual meetings of the Society of Biblical Literature and the American Academy of Religion in the mid-r 990s, I became aware of a new group that was formed in the AAR on ritual studies. At the same time, there was a section organized in the SBL on the social scientific study of the New Testament. As I attended, listened to papers, and saw a few scholars do a little bit on the Sermon on the Mount with ritual and social scientific studies, I thought that these avenues might provide a way to advance the idea of reading the Sermon on the Mount by looking at it as a ritual-based text-either as the actual performance of some kind of ritual or the preparation for entering into some kind of ritual. 


\section{Farnes: What type of ritual would that be?}

Welch: At a minimum it would be a covenant-making ritual. Again, the key for this understanding is right there in the Book of Mormon. At the end of Jesus' first day, he asked the people to enter into a covenant with him to keep the commandments which he had given them that very day. What he had taught them, especially in chapters I 2 to 14 , contained the commandments that they agreed, by way of covenant, in 3 Nephi 18 , to obey. Now, if it is true in the Book of Mormon that the Sermon at the Temple is a covenantmaking text, it seems logical to see the Sermon on the Mount in the Bible through a similar lens. It is easy to see how the Sermon on the Mount could have been used to prepare people, for example, for entering into the baptismal covenant. Indeed, from the latter part of the first century, we have a Christian text called the Didache, or the Teachings of the Twelve Apostles. There are lots of similarities between the Sermon on the Mount and the Didache, and we know that the Didache was used as a prebaptismal catechism. Or perhaps the Sermon on the Mount could have been used in preparation for receiving the oath connected with the Melchizedek priesthood (see Hebrew 7:20-2I). It could have been connected with several kinds of covenant-making ordinances. In any event, I submitted a proposal to the SBL section putting forth the idea of reading the Sermon on the Mount in the light of ritual studies. This took me into a new field of studies. I had presented several times before in the SBL Biblical Law section but never before in this section on social scientific study of the New Testament.

\section{Farnes: Was it diffcult transitioning into the new section?}

Welch: Yes, I saw it as quite a challenge, and I wanted to do a good job. Since I have a law degree, I figured I might pass as a kind of social scientist, but I was venturing here outside of my comfort zone. I was very pleased when the proposal was accepted; the paper was presented at the SBL meeting in Boston in 1999. That was the first time that the idea was vetted by a rigorous selection process. The session was quite large. The four other people on the panel with me were people whose names were iconic in that field. They were among those who had created the field of social scientific study of the Bible. So I was pretty nervous about how they would accept my thesis. Fortunately, I had been able to find a place to quote one of them, favorably, in my presentation, and that never hurts. As I sat there waiting my turn for the first two hours of this session, I started getting pretty nauseous. I usually do not get very nervous, but I really felt like I was not going to make it through the 
session. So I started taking deep breaths and saying prayers, and I was really wobbly. I almost fell when I walked up to the microphone, which happened to be on a riser which was really uneven. But I felt very blessed and fortunate. As I started speaking, everything went smoothly. I felt calm, and I could not have hoped for a better presentation.

\section{Farnes: What was the reaction?}

Welch: Well, since I was the last one in that session and I left some time for Q\&A at the end, I was able to go on as long as people wanted to stay. The first reaction was that the moderator did not cut off the questions and answers, which is kind of unusual. It was an afternoon session, but there were lots of hands being raised, positive comments made, and people saying, "Have you read this?" "What about this?" Fortunately, I had read the things they were suggesting. Two main things are memorable to me even today. One is that there was a man who stood up toward the back, a young South African scholar named Jonathan Draper who was heavily involved in the social scientific study of the oral transmission of texts. Since rituals and ceremonies are in the oral mode, my paper was particularly interesting to him. Jonathan was really interested and made some very encouraging comments and wanted to communicate with me, and to this day he and I are still good friends.

Farnes: You cite him a couple of times in your book.

Welch: I do, indeed. One of his specialties is the Didache. So it was natural that he would take an interest in my work, and vice versa. More recently he invited me to present a related paper in his SBL Didache section. So there was that memorable thing. But the second memory is of a woman who came up to me after the session had ended. She looked like she was near retirement. She taught at a small college. She said, "I just want to thank you for your presentation. I have been coming to SBL meetings all my academic life, and this is the first time I have felt the Spirit in one of our meetings. Thank you for bringing the Spirit into this room."

Farnes: That is an honor.

Welch: Yes, I felt very honored that she would share her feelings with me, a stranger to her. It made all the effort very worthwhile. Making the words of the Savior clear and understandable will always bring the Spirit to someone who is ready to listen.

Farnes: Going back to the Sermon at the Temple, in 3 Nephi, the group is all people who are prepared, who are righteous, who did not perish in the tribulation. 
The audience in Matthew is quite different. In my mind, to impose this audience upon the other audience is a problem. How would you answer that?

Welch: Well, I would first ask, what makes you think that the audience in Matthew 5 is the general public? Matthew 5:I begins by saying, "Seeing the multitudes, he went up into a mountain: and when he was set, his disciples came unto him." When they came off the mountain, there were multitudes down below, but it was only his disciples who came down with him. I think that Jesus spoke on both of these occasions to groups of faithful, righteous people. We have a clue of this in the gospel of Matthew, who wants us to see Jesus as going up into the mountain. That is how the Greek reads in Matthew 5:I: eis to oros. And the parallel which I really did not appreciate until I was doing the 2009 book is with Moses who also went up into the mountain. Moses went up alone at first because the people said that they didn't want to go up there, with all the thundering and lightning-they saw it as a frightening place. So Moses went up alone. But he comes down, and the second time he goes up with seventy elders, righteous Israelites, who there see God. And in Exodus 19:3, 20, and 24:9 we find the same words, eis to oros. I think that Matthew wants us to see Jesus doing the same thing with his group of disciples who are either already committed or close to being committed to following him and accepting him.

Farnes: With the "new Moses" motif running throughout the book of Matthew, is this something that Jesus wanted to get across, or something that Matthew was doing?

Welch: There are lots of ways to see Jesus. He can be seen as the "new Moses," or the promised prophet-like-Moses (Deuteronomy i 8:18), but Matthew also shows Jesus as the Son of David, and the Syrian Christians saw Jesus as an echo of Joseph sold into Egypt. And there is also the Passover typology that sees Jesus as the Pascal lamb and the messianic suffering servant typology from Isaiah 53. I think is a mistake to see any of the Gospel writers thinking that Jesus was only one of those. Matthew actually drops the Moses typology after chapter $\mathrm{I} 0$, so there are lots of things going on beyond the similarities between the lives of Moses and Jesus. But still, we know that as early as the trial of Stephen, Stephen testifies that Jesus was the prophet-like-Moses who was promised. So at a very early stage, the Christians saw Jesus fulfilling the mold of Moses. Something we do not really know is whether Jesus wanted to be seen that way or whether Matthew and the other disciples used it as a way to help their fellow Jews to recognize who Jesus was. The Moses-Jesus 
typology is complex enough that the parallels are significant in showing the providential hand of God in the lives of Moses and Jesus. The conformity of the two was providentially meant to be.

Farnes: We have the Sermon on the Mount in Matthew 5-7. We have the Sermon on the Plain in Luke 6. Do you think these are accounts of two separate events, or how do you reconcile that one was on a mountain and one was on a plain?

Welch: As I have discussed in all three of these books, I see the Sermon on the Plain as being addressed to a Gentile audience; at least we know that the audience included Gentiles who were there. That speech was given down in the coasts near Sidon, and in that area on the western parts of Galilee there were lots of Gentiles (Luke 6:1 7; 7:I). And so for me, the Sermon on the Plain was a trimmed down, shortened version of the longer text in Matthew, and with some significant differences; and if you go through and take out of the Sermon on the Mount the things that are most sacred or holy, or the things that would pertain primarily to a covenant-making context, you essentially have Luke's sermon. The strongest temple elements are not present in Luke 6, for some reason. So for example, Jesus in Matthew 7:6 tells people not to give "the holy thing" to the dogs, but he does not say that to the Gentiles in Luke 6 , presumably because what he had given them had not yet included "the holy thing." He has not given them the full covenantal relationship or instructions and insights that are not to be shared indiscriminately with all people. When he talks in Matthew 5 about how you should swear your oaths-saying, Do not swear by the heavens or earth, do not swear by your head, but just say yes or no-that instruction is relevant in a covenant-making context; it is not so relevant if you are talking to a general public audience, and it is not there in Luke 6. What this says to me is that Jesus probably gave the sermon, or parts of it, many times. I think that it is wrongheaded for people to go looking for the original text as if Jesus only gave the Sermon on the Mount once, that he set it in concrete in a first edition, and all we need to do is reconstruct a critical text that will get us back to what he said on that one occasion. Anybody who has been a missionary knows that you give the first missionary discussion a lot of times. And although they will have the same basic words and essential elements, each presentation is a little different as you work with people and prepare them personally for some kind of sacred experience. For many reasons, I think that it is unlikely that Jesus would have given the Sermon on the Mount only once. To me, that explains why careful New Testament scholars 
have rightly found that Matthew's source seems to be independent from the source that Luke is using. And some New Testament scholars have concluded that both Q Matthew and Q Luke contained a speech of Jesus, but they were not necessarily the same, identical text. I have suggested that they both could have been original with Jesus.

Farnes: Would another example of that be the injunction in Matthew, "Be ye therefore perfect," but in Luke, "Be ye therefore merciful"?

Welch: Exactly. That is a good point. The command to be perfect, to be teleios, is a word that fits in a temple and ritual setting. It does not mean to be perfect in a 100 percent kind of way, but it means to be finished or to be brought, as Moroni says, "to the finisher of their faith" (Moroni 6:4) and to be perfected in Christ. In a number of Greek texts, this word is used to refer to those going through the complete process of initiation into a religion. Now if Jesus is talking to one kind of a faithful group in Matthew 5, the use of this word in that context makes perfect sense, but, like you say, out on the plain he commands people, "Be ye therefore merciful" (Luke 6:36), a more general step of being kind, forgiving, and considerate.

Farnes: Tell us about the new book, which is a bit pricey, so it may not be on the bookshelf of every Latter-day Saint.

Welch: True enough. The new book is rather expensive, aimed as it is at an academic, non-Mormon audience, not for the bookshelf of every Latterday Saint, especially since the 1999 book is now available free online on the Neal A. Maxwell Institute website (maxwellinstitute.byu.edu). But let me tell you the story of how this new book came about. A few years ago, Noel Reynolds brought Margaret Barker, a Methodist temple-studies scholar from England, to BYU to run a weeklong seminar for anyone who wanted to come and read her materials on temple theology and temple themes. She had published some of her most recent publications in that area, and it was a very stimulating seminar. Without agreeing with everything that Margaret Barker said, people saw lots of ways in which her insights, intuitions, and even inspiration helps us spot some significant themes that we have missed. As I was driving Margaret out to Thanksgiving Point for a dinner after one of those days of presentation, we got talking about her projects and how the seminar was going, and as we were driving up I- I 5 , there on the right was Mount Timpanogos and the Mount Timpanogos Utah Temple. I started asking her what work she had done on temples, mountains, and theophanies, and she of course started going through a lot of the things about holy mountains that are 
familiar to many people. After she had committed herself sufficiently to the idea that "the mountain" is always a symbol of the temple, I said, "Well, then what would you think about the idea of seeing the Sermon on the Mount as a temple-related text?" It took her a minute to catch her breath, but she said, "That is astonishing. I had never thought about that. That is amazing. What makes you think that?"

"Well," I answered, “ 3 Nephi I I - I 4, for one thing," and then I mentioned some of the things I had written. Since the Book of Mormon had come up on several occasions in her seminar that week, she understood quickly what I meant by this. We talked about the ideas in the 1999 Sermon at the Temple book all the rest of the way out to Thanksgiving Point. She expressed a great interest in reading that book, and I told her a little about my presentation at SBL and that it had been well received. I gave her the book the next morning. Before she left Utah, she had read enough of it that she pulled me aside and said, "Your book-you must write this book for the rest of us." And I said, "Well, that will be hard because a lot of my evidence comes from the Book of Mormon. We do not have an explicit covenant-making context in Matthew. We do not have an explicit temple setting there." She said, "You can make the case without the Book of Mormon." And I said, "Well, that was what I tried to do in my SBL paper, where I primarily drew on ritual studies. What I have not done is to go back carefully through the Greek text of Matthew 5-7 to look at every word and every phrase with temple lenses on, to see how those words would have been understood by members of an audience who saw themselves in some kind of a temple context." From that point forward, Margaret remained very supportive. We communicated back and forth, and I kept shooting her ideas, and she came back with others. We got together once at Cambridge to go over a lot of these new details. Out of all that came the 2009 book from Ashgate in England.

Farnes: So what new insights occurred to you in this most recent study that you had not previously thought of?

Welch: First, I needed to build a strong case about the mountain as the mountain of the Lord, namely the temple. There is a whole new chapter on this which emphasizes the Moses-Sinai connection with "the mountain" in Matthew 5:I and also the same phrase in Psalm 24:3: "Who shall ascend into the hill of the Lord (tis anabèsetai eis to oros tou Kyriou)?" The Greek is the same used in Matthew 5:1: "he went up into a mountain (anebe eis to oros)." Ascending into a mountain is an allusion back to Moses, and all this is clearly 
temple related. So my first task in the new book was to establish that a temple context was clearly in place, not just in 3 Nephi but also in Matthew.

As I looked at all the vocabulary of the Sermon on the Mount, I found that most of the interesting words in the Sermon on the Mount—not the ordinary, everyday words but the distinctive, interesting words-were also used in the Septuagint Greek version of the Old Testament, especially in temple contexts. In the end, I produced a chart that shows the most important of these temple themes or temple words in the Septuagint and also in the Sermon. Some of them may or may not be equally significant, but they all seemed worth noting.

Stage after stage in the Sermon, one finds temple vocabulary connections, such as in this verse: "Neither do men light a candle, and put it under a bushel, but on a candlestick" (Matthew 5:I 5). The Greek text actually reads "on the candlestick" (epi teen luchnian), but any trace of the "the" here got lost in the Latin (super candelabrum), because Latin uses neither definite nor indefinite articles. Well, the Greek word here for candlestick is luchnia. That word appears in the Greek Septuagint nine times, all nine of them being found in the instructions in Exodus 25 for the making of the menorah. The menorah is a temple symbol par excellence. And even if there is just a subtle allusion to the temple here, Jesus often would speak in double meanings. So this word can have an ordinary, household, ethical meaning that you should let your light shine before men; but it might at the same time have an esoteric meaning to anybody with ears to hear him saying, "Put your light on the menorah. Put your light together with the light of God on the tree of light and life. Bring your light and join it with the light other faithful people. And when they see all those good works, they will glorify God who is in heaven." That is what it means, to let your light shine in such a way that when people see your good works they will glorify not you, but God. That won't happen if you just put your candlestick out on a table in your home or at a town feast. But if your light is a part of the temple light, then who will they glorify? They glorify God.

Reading the text of the Sermon on the Mount this way, word by word, is something I do in the new book in much greater depth than I have ever done before.

Farnes: Has anyone done a study like this before?

Welch: I do not think anyone has ever done this before, let alone in such concentrated detail, especially focusing on connections with temple passages in the Greek Septuagint version of the Old Testament. 
Farnes: If they haven't seen the Sermon on the Mount as using temple vocabulary, what kind of text have they thought it to be?

Welch: Scholars have largely missed the boat by thinking that that the Sermon on the Mount is a collection of proverbs in the genre of wisdom literature. There are some sayings in the sermon that sound a little bit like proverbs, such as "Whatsoever ye would that men should do to you, do ye even so to them" (Matthew 7:I2). But the book of Proverbs is never quoted in the Sermon on the Mount. This text is not just about some peasant, a folk preacher, out on a hillside giving out ordinary instructions on how to be a good Galilean farmer or villager. The Sermon on the Mount is filled with promises of eschatological rewards; dire statements about the consequences of disobedience; and directions about fasting, prayer, purification, and reconciliation with God and brethren. That does not sound like proverbial literature.

Farnes: Then where do the words in the sermon come from, if not from Proverbs?

Welch: It turns out that this text is loaded with words from the Psalms. Some of its words and phrases are direct quotes from the Psalms, from the beginning word in the Beatitudes to the end of the sermon. The first word in Psalm I:I is makarios (blessed, singular). The first word in the Sermon on the Mount is makarioi (blessed, plural). Toward the very end of the sermon Jesus says, "Depart from me, ye that work iniquity" (Matthew 7:23). That is a verbatim quote from Psalms 6:8. And there are plenty of others like these in between. What this says is that the temple, which was, after all, the dominant religious institution in Jesus' world, is also the dominant rhetorical voice of the Sermon on the Mount, because the Psalms primarily, if not exclusively, had their home base in the temple. So I argue that this close affinity with the Psalms is a temple element that helps people to hear the words in this text with that temple register in mind. This book also makes an argument for the pervasiveness of this temple register, for every stage of the Sermon on the Mount can be understood this way. And the importance of that is that most people, in studying the Sermon on the Mount, cannot make all its pieces fit together. Understood otherwise, something always doesn't fit. In fact, usually, following other lines of analysis, one cannot account for most of it. For example, you might have a theory that the Sermon on the Mount is an antiPharisaical document. But then what do you do with about 90 percent of the text that has nothing to do with Pharisaical behaviors or concerns? But the 
temple analysis - or better said, the temple synthesis—of this text, brings a unity to the text that I think no other way of viewing it has been able to offer.

Farnes: This is one of the values of the book-to explain things that are opaque. From beginning to end, the sermon has a theme built on the temple. So what do you think will be the result of this book?

Welch: I hope that it will continue to bear good fruit. So far, my book only tries to explain and situate the Sermon on the Mount itself. The aftershocks of that, if that theory is accepted, will of course challenge a lot of the received wisdom about the sources that were used in writing the Gospels. I think we need to begin by rethinking the whole Gospel of Matthew as temple-related, not just Moses-related or Messiah-related, as we have more commonly seen it. People say that Matthew is preaching and writing to the Jews, but I think that all of the Gospels are written to Jewish people, one way or another. I think Matthew in particular offers a very interesting case study for seeing temple elements throughout what he has written. We know that Matthew was a Levite, although it is only Luke who tells us that. But that is, I think, a very significant disclosure, because, as a Levite, he would have worked in the temple at least two weeks a year, and probably more often.

Farnes: Many scholars say Matthew was a tax collector, a Roman publican. What are your thoughts on that?

Welch: Well, that is possible, but some people have argued that he could have been a collector of temple taxes, so he may have been a part of the temple financial administration, perhaps in addition to doing his regular Levitical duties. If that is so, then much of the Gospel of Matthew needs to be rethought. We might ask with each story he tells, "Why would a Levite be particularly interested in this particular story and the way in which it is presented?" For example, Matthew is the only one who tells us the story of the king who had a servant who owed him ten thousand talents and could not repay the debt and the king forgave him (see Matthew I 8). And then the servant goes out and will not forgive a fellow servant who owes him one hundred denarii. In Jesus' day, there was only one institution in all of Israel, if not all of the world, that had ten thousand talents in its treasury, and that was the Temple of Herod, according to Josephus. The subtext of the parable in Matthew i 8, then, may very well be that the king (the Lord God) has a servant (the high priest) who owes him these ten thousand talents that ought to be used for proper purposes, and when they're not, God is willing to forgive the high priest, but the high priest is not willing to forgive his fellow debtors. If that is something that 
a Levite, as an underling servant in the temple, might have really resonated with, then there may be some political motivations for telling that story-a story that otherwise seems to be so exaggerated and hyperbolic that we struggle to take it seriously. Of course, the Greek phrase translated as to "forgive" someone their debts in Matthew I 8 matches the phrase in the Lord's Prayer, "forgive us our debts." The end of the chapter about the unforgiving servant even ends with a direct paraphrase of the Sermon on the Mount, according to which God will only forgive you to the extent you forgive your fellowmen their trespasses (Matthew i 8:35).

Farnes: So it ties it right back in with a temple-related principle.

Welch: Yes, so we need to look at these connections within the Gospel of Matthew and also beyond. For example, what does all this tell us for studying the Epistle of James, which is loaded with Sermon on the Mount similarities? The epistle of I Peter also has plenty. Paul uses words and phrases from the Sermon on the Mount. My thesis would say that the Sermon on the Mount was already "coin of the realm" among these earliest Christians, in some form or other. It doesn't necessarily need to be Matthew's exact version that is circulating in all places, but I think the pervasiveness of elements from the Sermon on the Mount not only in the New Testament but in texts such as the Shepherd of Hermas and the Didache means to me that this key text was used, from the beginning, as a foundational text, as a part of their baptismal preparation, their covenant making, and their definition of what it meant to live as a follower of Christ. But think of the consequences of that! This approach reworks much of the common understanding of first-century Christianity, which is a pretty significant thing to propose.

Farnes: Very significant.

Welch: Another thing that we can do is begin to ask, "Why have people missed this? Why have Protestant scholars not seen this?" Indeed, Protestant scholars are quite uncomfortable (many of them, anyway, and Luther certainly among them) with the Sermon on the Mount because it just seems to be too works oriented. Maybe that's why James likes it so much. But Protestants don't naturally gravitate toward priestly or temple ordinance kinds of things, because to them, it was essential in their protest against Catholicism to put distance between their understanding of Jesus and the practices of the Catholic Church. Because of that, I think they may have perhaps unwittingly downplayed the importance of the temple and its elements in the life of Jesus. Nibley does a famous job of showing that there was initially a Christian 
envy of the temple, and that temple things were really important in early Christianity; but as with a lot of other important things, these fell out of favor and eventually off the table. I hope that my new book may help to bring some of that back on board and into focus.

Farnes: There definitely is a reaction to temple and ritual in Protestant theology and Protestant scholarship, which has identified some very interesting fields of study like, as you said, wisdom literature, which highlights the rhetorical skills of Paul and others; but if one goes down that road completely, yet gives up the ritual context, the results may have highlighted some interesting minor points but will have missed the bigger picture.

Welch: That's right. Well said.

Farnes: Well, congratulations on this remarkable achievement. This is a great book, and it is amazing to see something like this bringing to bear insights that come out of the Restoration but without needing to rely exclusively on those LDS details.

Welch: I hope, above all, that this book shows that we, as Latter-day Saints, do have a lot to offer to the world at large. As I've worked with people of many different religious persuasions, I have found that if you are kind and sincere and interested in what they are doing, they reciprocate, wanting to know what you think and what your tradition has to offer. This may not have been so much the case fifty years ago, but I think we are blessed to live in a time when so many doors are open and things are available. I think there are people out there who want to know what a Latter-day Saint perspective would be on any number of subjects. As scholars, we are in a position to offer those kinds of explanations in academic terms. And as disciples of the Lord, I think we are all obligated to be able to answer and to give a reason for the hope that is in us. So I am very glad that we live in a time when we can do this. Having said that, I think that this makes it all the more incumbent upon us to read and listen to the things that others are publishing and to understand how and why they are saying what they are saying. We need not dismiss their comments with disdain. We may still see that some of it is wrong or inconsistent with things that we would have said, but I usually find that, even in a work that is antithetical to a lot of my beliefs and that is based upon assumptions that I do not share, I am forced to think things through that I would not otherwise have thought about, and in that process I usually learn something new and signficant. . $\mathrm{E}$ 